\title{
Analysis of Manifestation of CC and CXC Chemokine Genes in Olive Flounders (Paralichthys olivaceus) Artificially Infected with VHSV during the Early Developmental Stage
}

\author{
Kyung-Hee Kim, Woo-Jin Kim, Choul-Ji Park, Jong-Won Park, Gyeong Eon Noh, \\ Seunghyung Lee, Young Mee Lee, and ${ }^{\dagger}$ Hyun Chul Kim \\ Genetics and Breeding Research Center, National Institute of Fisheries Science (NIFS), Geojesi 53334, Korea
}

\begin{abstract}
Chemokines is a small protein that plays a major role in inflammatory reactions and viral infections as a chemotactic factor of cytokines involved in innate immunity. Most of the chemokines belong to the chemokine groups CC and CXC. To investigate the immune system of the olive flounder (Paralichthys olivaceus), an expression pattern specifically induced in the early developmental stages of analysis is examined using qRT-PCR. We also examined tissue-specific expression of both CC and CXC chemokine in healthy olive flounder samples. CC and CXC chemokine shows increased expression after immune-related organs are formed compared to expression during early development. CC chemokine was more highly expressed in the fin, but CXC chemokine showed higher expression in the gills, spleen, intestines, and stomach. Spatial and temporal expression analysis of CC and CXC chemokine were performed following viral hemorrhagic septicemia virus (VHSV) infection. CC chemokine showed high expression in the gills, which are respiratory organs, whereas CXC chemokine was more highly expressed in the kidneys, an immune-related organ. These results suggest that CC and CXC chemokine play an important role in the immune response of the olive flounder, and may be used as basic data for the immunological activity and gene analysis of it as well as other fish.
\end{abstract}

Key words : Olive flounder Paralichthys olivaceus, Gene expression, CC chemokine, CXC chemokine, Viral hemorrhagic septicemia virus (VHSV)

\section{INTRODUCTION}

The olive flounder (Paralichthys olivaceus) is widely distributed around East Asian shores and is one of the most economically important marine organisms as it has a $40 \%$ share in local sea water fish culture. However, the survival rate of cultured olive flounders is seriously influenced by a variety of diseases, radical changes in temperature, and high-density cultures. In particular, fish in the larval phase are immediately exposed to various microorganisms, hence study on their effective immune system and diseases is a very important prerequisite for the improvement of survival rate (Zapata et al., 1997).

Viral hemorrhagic septicemia virus (VHSV) is known to cause mass mortality in olive flounders (Paralichthys olivaceus), rainbow trouts (Oncorhynchus mykiss), turbots (Scophthalmus maximus), etc. (Kim et al., 2009; Pinheiro et al., 2016; Pereiro et al., 2016). The spleens of infected

\footnotetext{
Manuscript received October 2, 2018, Received in revised form October 17, 2018, Accepted November 5, 2018

${ }^{\dagger}$ Corresponding Author : Hyun Chul Kim, Genetics and Breeding Research Center, National Institute of Fisheries Science (NIFS), Geojesi 53334, Korea. Tel: +82-55-639-5814, E-mail: hckimgnu@Korea.kr
}

This is an Open Access article distributed under the terms of the Creative Commons Attribution Non-Commercial License (http:// creative-commons.org/licenses/by-nc/3.0) which permits unrestricted non-commercial use, distribution, and reproduction in any medium, provided the original work is properly cited. 
fish are bloated, full of ascites, and cause extensive bleeding in both internal and external organs including the fins, gills, and eyes (Isshiki et al., 2001; Duesund et al., 2010). Moreover, it has a rapid infection speed and occurs frequently in locally cultured olive flounders (Kim et al., 2003).

The immune system is a biologically important system that blocks the invasion of pathogens, maintains homeostasis, and protects the organism from antigens. In the case of fish, they live in an aqueous environment from the fry stage and depend on their congenital immune systems for survival. The congenital immune system is the first line of protection against various microorganisms and is essential for controlling pathogenic infection (Beck \& Habicht, 1996; Fischer et al., 2013).

Chemokine, a main chemoattractant of cytokine that is concerned with congenital immunity, plays the important role of directing the movement and activation of leukocyte across the entire body (Luster, 1998; Mantovani, 1999). Chemokine is divided into $\mathrm{CC}, \mathrm{CXC}, \mathrm{CX} 3 \mathrm{C}$, and $\mathrm{C}$ chemokine according to the composition of $\mathrm{NH}_{2}$-terminal cys residue (Hsu et al., 2013). In addition, in the immune system, chemokine may be divided into homeostatic chemokine and inflammatory chemokine. In immune reactions, chemokine generally is involved in attracting immunocytes to the damaged region and removing pathogens through phagocytosis.

Most chemokine belongs to the $\mathrm{CC}$ and $\mathrm{CXC}$ chemokine groups (Murphy et al., 2000). CC chemokine has 2 close cysteines near the terminal of the amino acid and induces the movement of monocytes including NK cells, dendritic cells, and other types of cells. In addition, it is a strong chemoattractant of monocytes, lymphocytes, basophils, and eosinophils (Miller \& Krangel, 1992; Taub \& Oppenheim, 1993; Murphy, 1994). CXC chemokine has 2 cysteines and another amino acid that is expressed as " $\mathrm{X}$ " in the N-terminal, and in the case of mammals, it is classified according to the existence of glutamic acid (E) - leucine (L) - arginine (R) (ELR motif) directly before the first cysteine (Oppenheim et al., 2001). Specifically, a positive ELR motif induces the movement of neutrocytes and acts as coaction of the chemokine receptors CXCR1 and CXCR2. Moreover, it is interleukin-8 (IL-8) that induces neutrocytes to drop into blood flow and enter surrounding tissues. Negative ELR motif, such as CXCL13, has chemical attractancy to lymphocytes (Bazan et al., 1997; Pan et al., 1997).

Chemokine in modern fish is reported in Atlantic cod (Gadus morhua), Atlantic salmon (Salmo salar), channel catfish (Ictalurus punctatus), large yellow croakers (Larimichthys crocea), olive flounders (Paralichthys olivaceus), rainbow trout (Oncorhynchus mykiss), rock breams (Oplegnathus fasciatus), zebrafish (Danio rerio) and others, however, information on immune reaction is limited (Bao et al., 2006; Borza et al., 2010; Grimholt et al., 2015; Khattiya et al., 2004; Kim et al., 2013; Knaut et al., 2003; Semple et al., 2018; Zhou et al., 2018). Therefore, in this study, in order to examine the immune system of fish, analysis was performed on the gene expression of CC and CXC chemokines at different stages and in different tissues of olive founders during the initial occurrence stage and after VHSV infection in the gills, spleen, and kidneys.

\section{MATERIALS AND METHODS}

\section{Sampling}

Olive flounders used as test subjects were bred in a 5 ton round water tank at a water temperature of $19 \pm 1^{\circ} \mathrm{C}$ with a light period of 15 hours and a dark period of 9 hours at the Breed Research Center of the National Fisheries Research and Development Institute. To observe gene expression at different stages of development, samples taken from test subject up to 18 days after hatching were put in Trizol Reagent (Invitrogen) and stored at $-80^{\circ} \mathrm{C}$ until RNA separation. To analyze gene expression in different tissues, the brain, eyes, fins, gills, intestines, kidneys, liver, muscles, spleen, and stomach were extracted from a healthy 8month-old olive flounder (total length of approximately 30 
$\mathrm{cm})$ and stored at $-80^{\circ} \mathrm{C}$ until testing.

\section{Artificial VHSV infection test}

Artificial VHSV infection testing was performed on healthy olive flounders (total length of approximately 30 $\mathrm{cm}, 8$ months old) by dividing them into control and test groups. The test subjects were moved to a 3 ton round water tank and not fed on the day of or the day prior to inoculation. The test was performed at a water temperature of $13^{\circ} \mathrm{C}$ with a light period of 15 hours and a dark period of 9 hours. The control group was inoculated with $100 \mu \mathrm{L}$ of phosphate buffered saline (PBS) solution and the test group was inoculated with a VHSV suspension $\left(10^{4.8} \mathrm{TCID}_{50}\right.$ virus/ fish) (Kong et al., 2009). Sampling was performed from the gills, spleen, and kidneys of olive flounders $0,1,6,12$, and 24 hours after inoculation. Stress on test subject was minimized through anesthesia using MS-222 (Sigma, USA) at a concentration of $150 \mathrm{ppm}$ (Noh et al., 2017) and each tissue was stored at $-80^{\circ} \mathrm{C}$ until testing.

\section{Separation of RNA and qRT-PCR}

Total RNA was extracted from test olive flounders using a TRI solution (BSK-Bio Co.). Genomic DNA contamination of the extracted RNA was removed using DNase-I and qualitative and quantitative quantities were measured using a spectrophotometer (BioTek, Gen5.2). The cDNA of the total RNA was synthesized using oligo-d(T) $)_{18}$ primer and a
Transcriptor First Strand cDNA Synthesis Kit (Roche Ltd., Switzerland), and qRT-PCR (ABI 7500, Applied Biosystems) was performed under the following conditions to confirm the gene expression of $\mathrm{CC}$ and $\mathrm{CXC}$ chemokine in the olive flounders (Lee et al., 2018). After performing the initial denaturation process for 20 seconds at $95^{\circ} \mathrm{C}$, annealing and elongation were performed for 30 seconds at $58^{\circ} \mathrm{C}$ and $60^{\circ} \mathrm{C}$ respectively. $18 \mathrm{~S}$ rRNA was used as the internal standard control and the gene expression ratio of $18 \mathrm{~S}$ rRNA was quantified using the $2-{ }^{\Delta \Delta C t}$ method. In addition, Primer3 CC chemokine, CXC chemokine, and 18S rRNA primer of the olive flounders were designed using the Primer3 program and are shown on Table 1 .

\section{Statistical analysis}

All samples were performed three times for accuracy and all data were expressed in average \pm standard deviation $(n=3)$. Significant differences in data value were checked via one-way ANOVA. Significance testing of the gene expression between each entity was performed using Tukey's HSD test at $p<0.05$.

\section{RESULTS}

1. Gene expression of $C C$ and $C X C$ chemokine during early development stage

To investigate the congenital immune reaction of olive

Table 1. Oligonucleotide primers used in this study

\begin{tabular}{cccc}
\hline \hline Primer name & Sequence $\left(5^{\prime}{ }^{\prime} 3^{\prime}\right)$ & GenBank accession & no. \\
\hline CC chemokine-LP & CCCAGTGCTCTGCAACAGTA & AU090535.2 \\
CC chemokine-RP & CGAACACCTGGAGTCAGTCA & \\
\hline CXC chemokine-LP & TCGGCCGCTACATTAAGAGT & AB070837.1 \\
CXC chemokine-RP & TTAAACGGCTCTGACCCATC & \\
\hline 18 S rRNA-LP & ATGGCCGTTCTTAGTTGGTG & EF126037.1 \\
\hline CACACGTGATCCAGTCAGT & \\
\hline
\end{tabular}


flounders, the gene expression of CC chemokine, CXC chemokine, and mRNA were analyzed beginning from the initial occurrence stage in olive flounders until 18 days after hatching. Quantitative analysis was performed on CC and CXC chemokines of olive flounders by qRT-PCR using gene specific primer. Relative gene expression of mRNA at each occurrence stage was calculated using the olive flounder reference gene $18 \mathrm{~S}$ rRNA, and relative tissue specific gene expression was investigated by comparing the results with the eggs. $\mathrm{CC}$ chemokine increased at day 4 after hatching (2.27-fold), began to slowly decrease starting from day 5 (1.44-fold), and reached minimum value at day 13 (0.27-fold). Subsequently, the value began to slowly increase starting on day 14 (1.23-fold) and reached maximum gene expression at day 18 (3.26-fold) (Fig. 1A). CXC chemokine started increasing from day 1 after hatching (1.1-fold) and continued to increase until day 4 (7.55fold). The value subsequently slowly decreased until day 7 (2.59-fold) and reverted to increase until day 9 (6.78-fold). Then, identical to CC chemokine, the value of CXC chemokine showed minimum gene expression on day 13 (0.52fold) and started to slowly increase after day 14 (1.07fold), reaching maximum gene expression on day 18 (9.67fold).

\section{Gene expression of $C C$ and $C X C$ chemokine in different tissue}

To observe the gene expression of $\mathrm{CC}$ and $\mathrm{CXC}$ chemokine in tissue, we extracted brain, eye, fin, gill, intestine, kidney, liver, muscle, spleen, and stomach tissues from healthy olive flounders and investigated gene expression using qRT-PCR. Relative mRNA gene expression was calculated for each using olive flounder reference gene $18 \mathrm{~S}$ rRNA, and relative tissue specific gene expression was investigated by comparing the results with brain tissue. CC chemokine showed the highest gene expression in the fin (2.6-fold) compared to other tissues and showed relatively low gene expression in the liver ( 0.3 -fold) and spleen (0.2-fold) (Fig. 2A). CXC chemokine showed both the highest and lowest gene expression in the gills (106.6fold) and brain (1-fold), respectively (Fig. 2B). Furthermore, the spleen (24.3-fold), intestine (21.2-fold), stomach (13.1-fold), and muscle (10.2-fold) also showed high gene expression (Fig. 2B).

\section{Gene expression of CC and CXC chemokine fol-} lowing artificial VHSV infection

To study the functions of $\mathrm{CC}$ and $\mathrm{CXC}$ chemokine on immune reaction against viral infection, the gene expression of olive flounders artificially infected with VHSV was recorded according to time elapsed. Relative mRNA gene expression for each time period was calculated using olive flounder reference gene 18S rRNA and relative tissue specific gene expression was investigated by comparing the results with those from 0 hours, the starting point of artificial infection. $\mathrm{CC}$ chemokine showed high gene expression in the gills at 12 hours after inoculation (4.7-fold), and in the kidneys, it showed a tendency to decrease after 0 hours (1-fold) (Fig. 3A). Moreover, in the case of the spleen, no overall significant difference was seen (Fig. 3A). CXC chemokine in the gills did not show a large difference from 0 hours to 6 hours after inoculation of the virus and showed a tendency to decrease starting from 12 hours $(0.5$-fold $)$ (Fig. 3B). In the case of the kidneys, high gene expression was seen at 12 hours (2.4-fold). In the spleen, it showed significant difference from 0 hours (1-fold) to 12 hours (1.2-fold) and started to decrease slowly from day 1 (0.7-fold) (Fig. 3B). CC chemokine after artificial VHSV infection showed high gene expression in the gills, while CXC chemokine showed high gene expression in the kidneys (Fig. 3).

\section{DISCUSSION}

Fish, unlike other vertebrates, live in an aquatic environment from their egg stage and are therefore strongly exposed to various pathogens from the fry stage. Their 
A

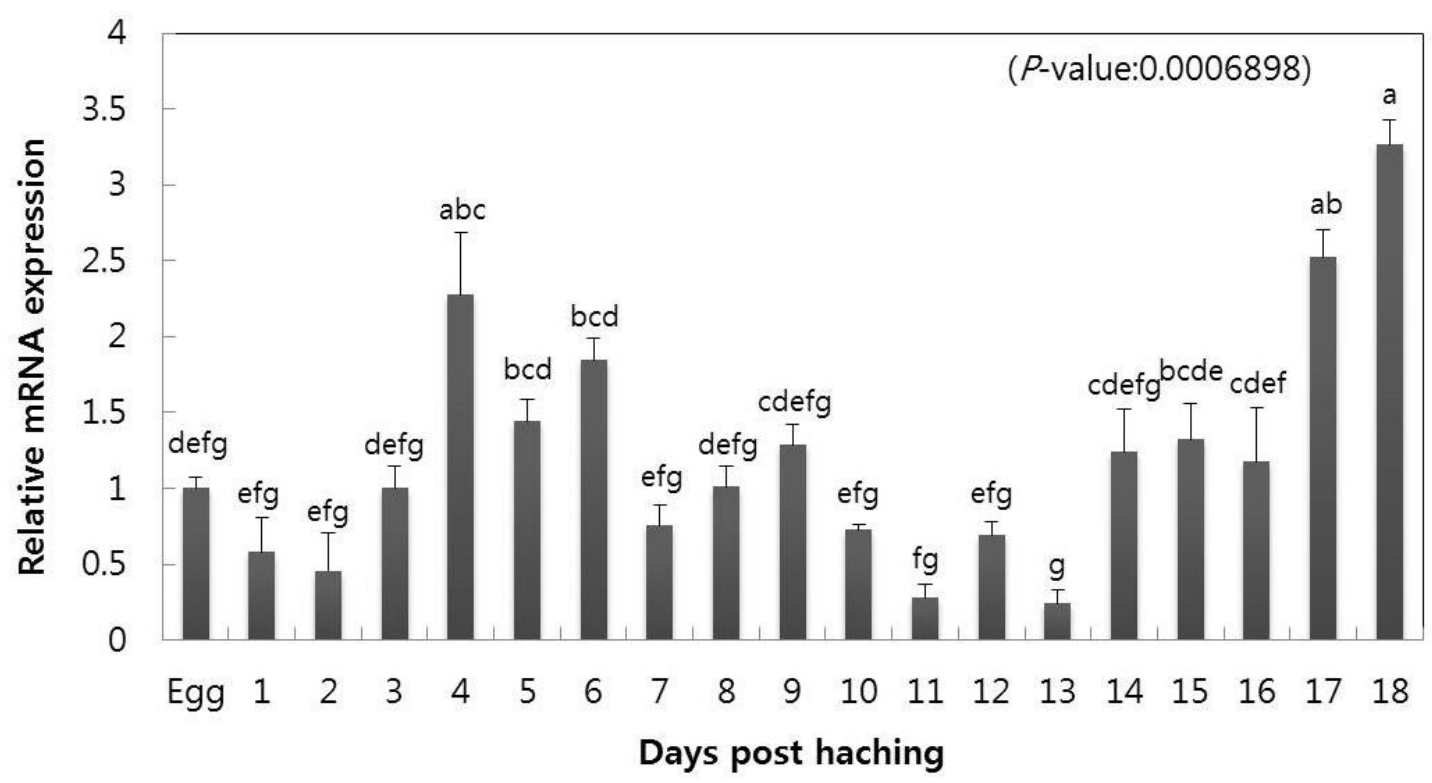

B

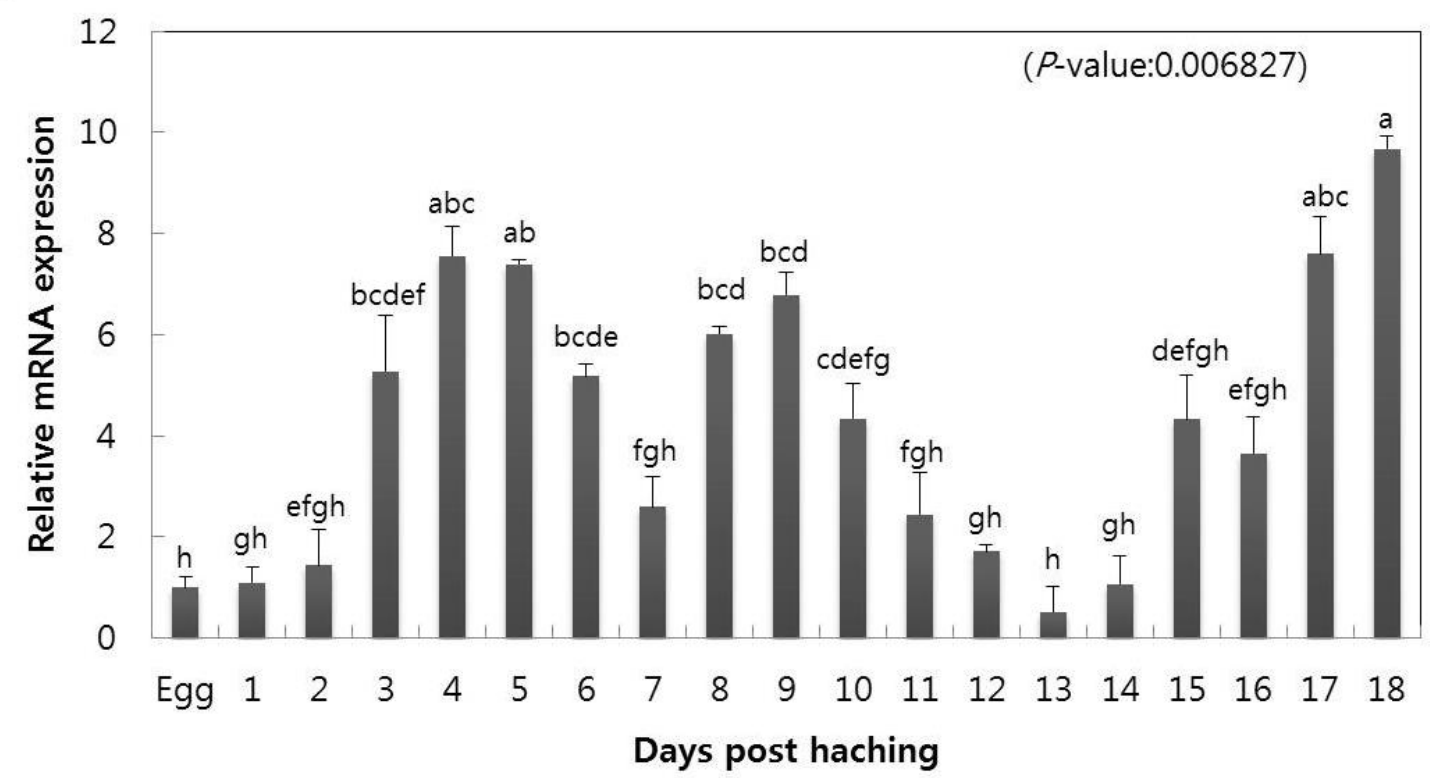

Fig. 1. Expression analysis of CC chemokine (A), CXC chemokine (B) mRNA in different developmental stage. The mRNA expression of CC and CXC chemokine was analyzed via qRT-PCR from fertilization though to 18 day old larvae. Each experiment was performed in triplicate and the expression levels of 18S rRNA and CC and CXC chemokine at the egg stage were set as 1 .

immune system, such as their marrow and lymphatic glands, are not as well evolved as mammals, however, antibodies are produced and microorganisms are destroyed through congenital immune reactions (Magnadottir, 2006). Accord- ing to Kim (2009), the larvae of olive flounders develop primordial finfolds immediately after hatching, the mouth and anus open at day 4 , and the gills open at day 6 . In addition, the digestive canal expands towards the stomach 

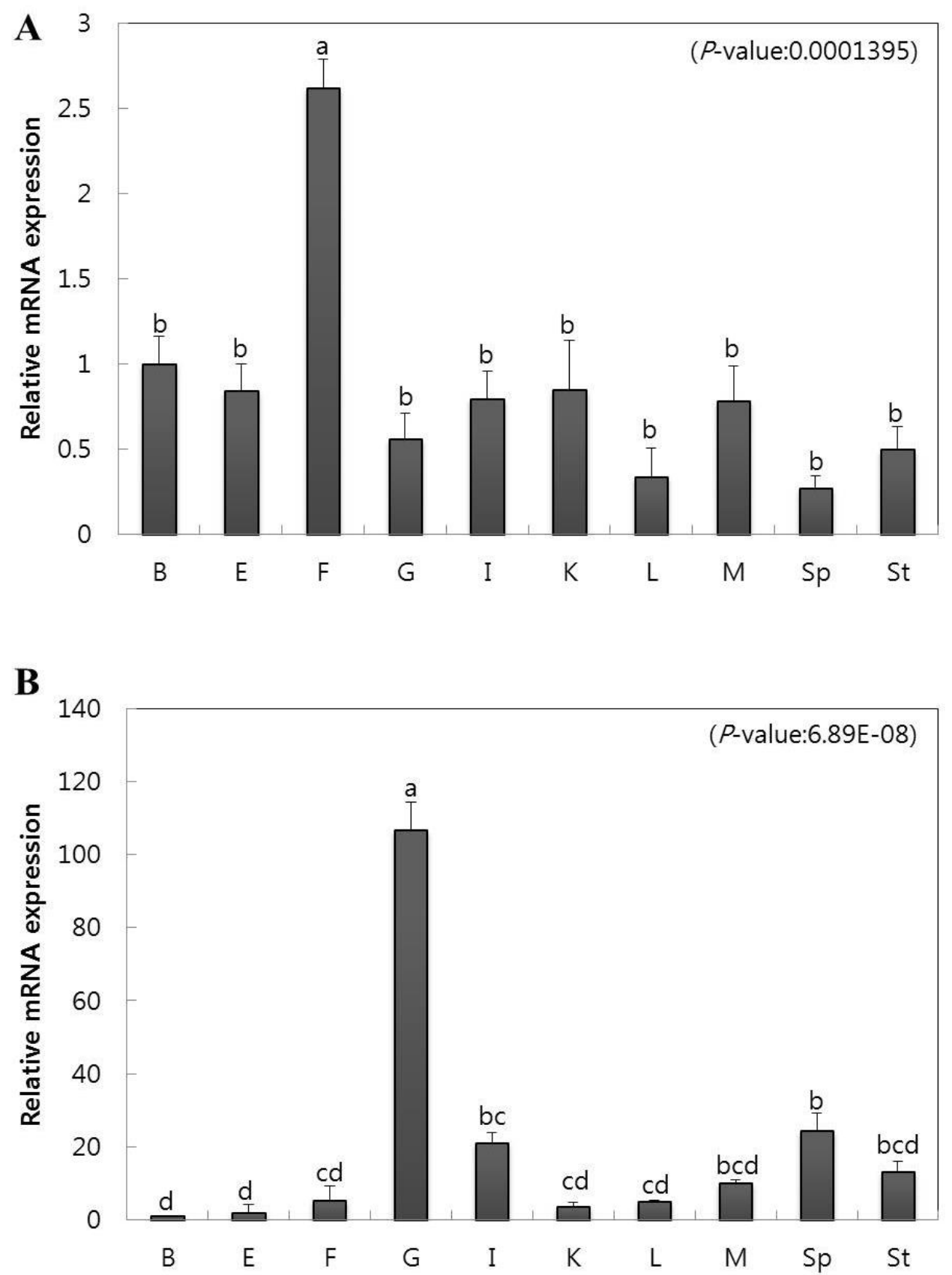

Fig. 2. Expression analysis of CC chemokine (A), CXC chemokine (B) in different tissues in Olive Flounder Paralichthys olivaceus. CC and CXC chemokine expression in different tissues was determined via qRT-PCR. Each experiment was performed in triplicate and the expression levels of $18 \mathrm{~S}$ rRNA and $\mathrm{CC}$ and $\mathrm{CXC}$ chemokine at the brain were set as 1. B, brain; E, eye; F, fin; G, gill; I, intestine; K, kidney; L, liver; M, muscle; Sp, spleen; and St, stomach. All assays were performed in triplicate.

and is connected to intestines while the stomach starts to develop and the larvae beings planktonic life. It is reported that the digestive canal becomes completely divided into the esophagus, foregut, midgut, and hindgut by day 14 while the digestive canal continues overall development alongside the growth of body, and that the liver grows in size significantly by day 18 . Therefore, when comparing with the results of this study (Fig. 1), it can be seen that the 
A

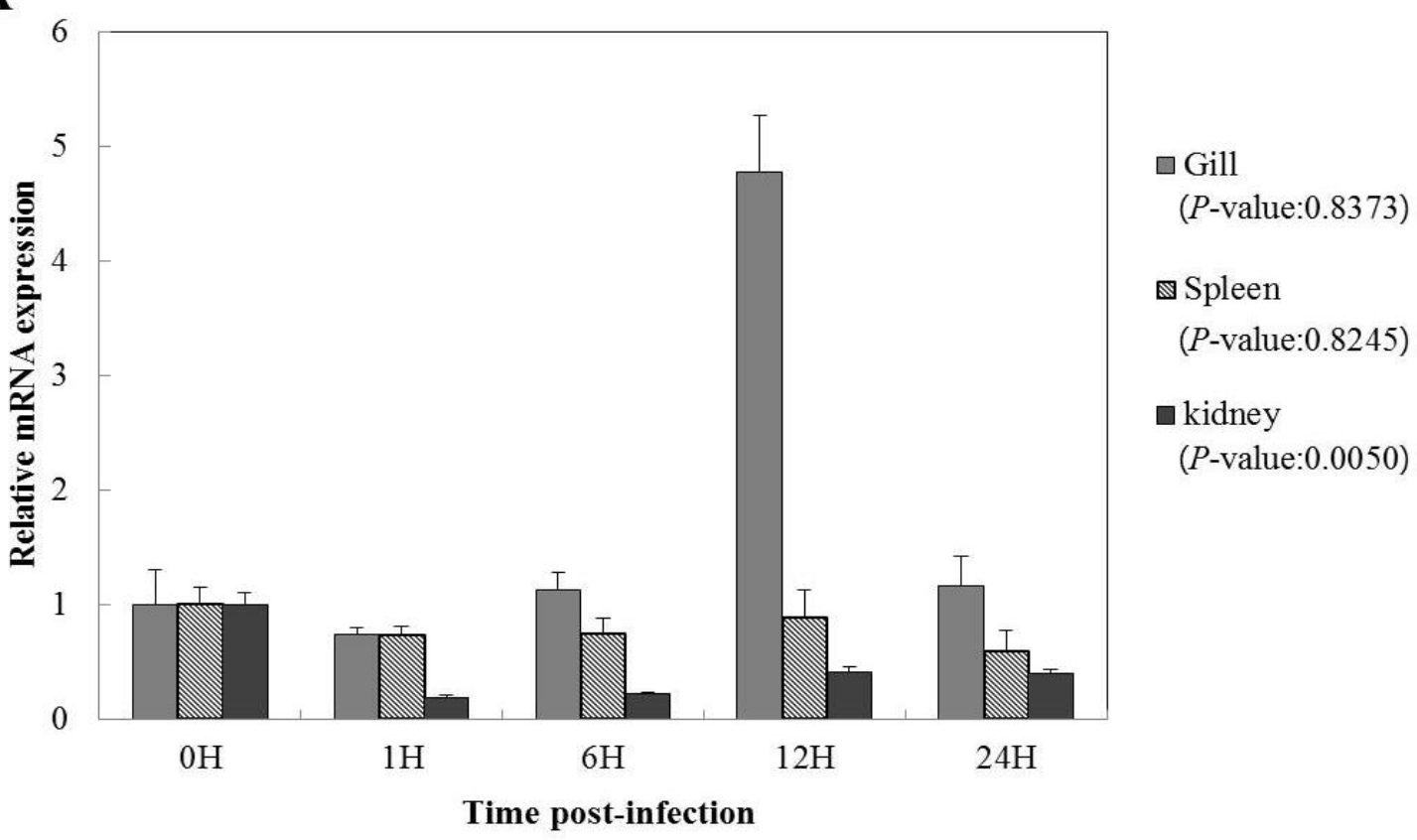

B

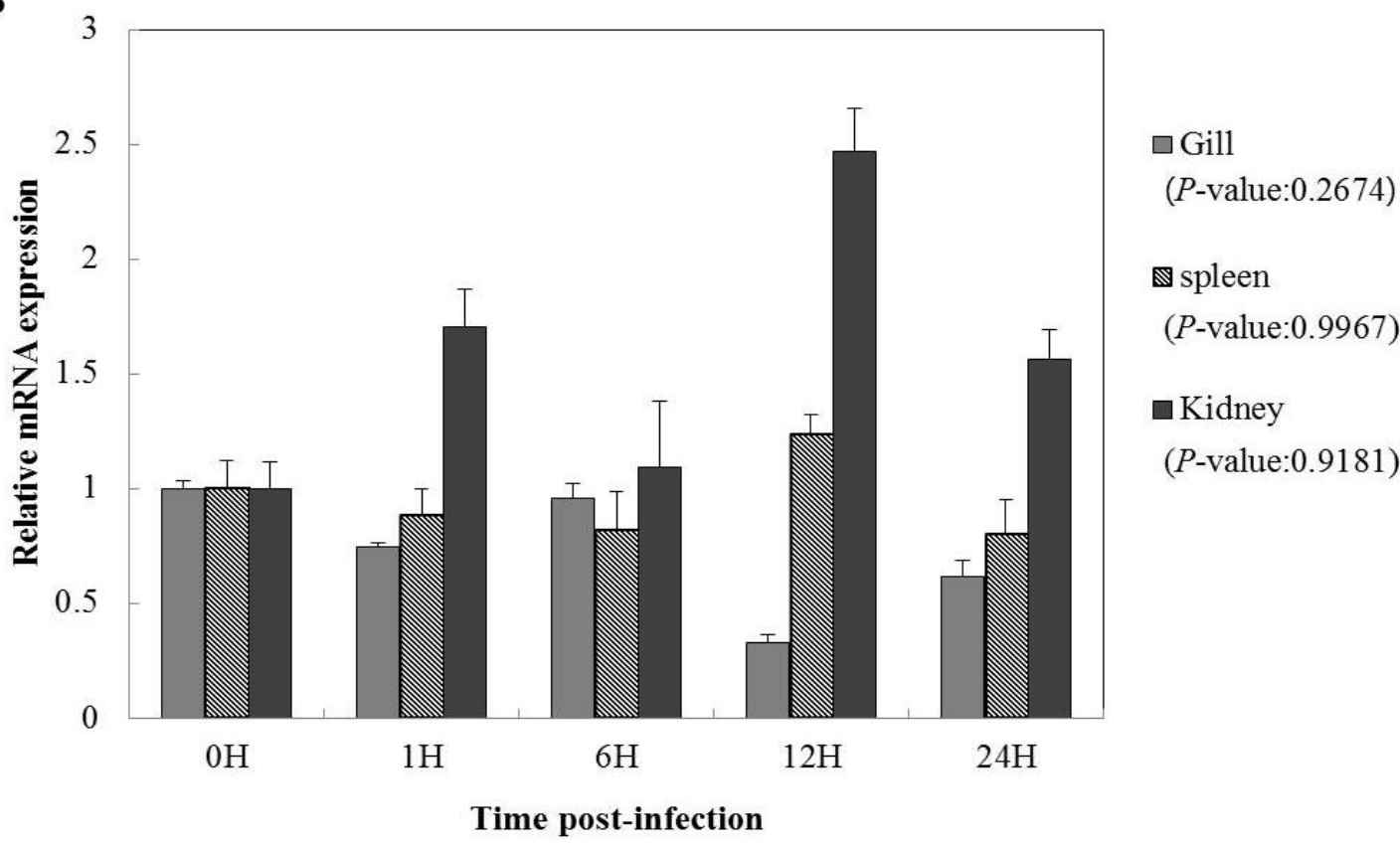

Fig. 3. Temporal distribution of CC chemokine (A), CXC chemokine (B) mRNA in various tissues following VHSV infection. The expression level of CC and CXC chemokine was determined in the gills, spleen, and kidneys via qRT-PCR. The samples were analyzed at $0,1,6,12$, and 24 hours post-injection. Each experiment was performed in triplicate and the expression levels of $18 \mathrm{~S}$ rRNA and CC and CXC chemokine at $0 \mathrm{~h}$ were set as 1 . VHSV, viral hemorrhagic septicemia virus.

gene expression of $\mathrm{CC}$ chemokine and $\mathrm{CXC}$ chemokine increases at day 4 when the mouth and anus open and that the maximum gene expression is shown when the digestive canal is divided and the body grows significantly. The re- 
sults show that $\mathrm{CC}$ chemokine and $\mathrm{CXC}$ chemokine manifest beginning at the egg stage through to the late stage larval stage, and it can be seen that gene expression increased during the late stage where immune tissues are formed rather than during the initial occurrence stage.

$\mathrm{CC}$ chemokine is known to play an important role as a signal material, namely as a chemical chemoattractant, that can attract certain immunocytes, (Xu et al., 2011). Looking at the gene expression of $\mathrm{CC}$ chemokine in the tissues of various fish, rock breams (Oplegnathus fasciatus), large yellow croakers (Pseudosciaena crocea), and trout (Scophthalmus maximus) showed high gene expression in the spleen, kidneys, and intestine, while miiuy croakers (Miichthys miiuy) showed high gene expression in the fins (Zhang \& Chen, 2008; Chen et al., 2010; Xu et al., 2011; Kim et al., 2013). In addition, in the same manner with CC chemokine in most fish, it can be predicted that in this test (Fig. 2A), CC chemokine manifested in a variety of tissues to provide a homeostatic function through immunosurveillance rather than to function as chemoattractant in immune- related tissues. CXC chemokine, like in other fish, manifested in all tissues (Fig. 2B) and showed high gene expression in the gills, spleen, and kidneys, similar to large yellow croakers (Tian et al., 2010) and rock breams (Oplegnathus fasciatus). However, the degree of gene expression contrasted with this test which implies that gene expression of CXC chemokine in fish tissues may vary by species.

The transient changes in CC and CXC chemokine was analyzed using various inflammatory mediators, and the results are known to play an important role, mainly in the immune response (Kim 2012; Hsu et al., 2013; Kim et al., 2013; Zhou et al., 2018; Semple et al., 2018). Therefore, we aimed to observe the immune response of $\mathrm{CC}$ and $\mathrm{CXC}$ chemokine through an artificial VHSV infection. AS result of performing subtractive suppressive hybridization using rainbow trout infected with VHSV, CXC chemokines play an essential role in virus defense (Liston \& McColl, 2003;
Farrell et al., 2002). The kidneys have abundant leukocytes and are an immune-related organ with various immunocytes (Uribe et al., 2011). Therefore, it is thought that the high expression of CXC chemokine as the time elapses in the kidney plays an important role in the immune response of fish (Fig. 3B). However, it is deemed that high gene expression of $\mathrm{CC}$ chemokine in the gills is due to exposure to the aquatic environment because, as a respiratory organ that is in charge of discharge and osmoregulation, it is an invasion pathway for countless microorganisms (Fig. 3A; Kim, 2012). Whether these results are related to the role of immune defense requires further investigation.

In this study, analysis of the gene expression of $\mathrm{CC}$ and CXC chemokine was performed to examine the immune reaction of fish, and as a result, it is thought that both the CC and CXC chemokines play an important role in the congenital immune system of fish. It is hoped that this study will become valuable baseline data in the study of immune reaction of fish in the future. Additional study on the $\mathrm{CC}$ and $\mathrm{CXC}$ chemokines in post larval phases where immune tissues are completely formed shall be necessary.

\section{ACKNOWLEDGEMENTS}

This work was supported by a grant from the National Institute of Fisheries Science (R2018001).

\section{REFERENCES}

Bao B, Peatman E, Peng X, Baoprasertkul P, Wang G, Liu Z (2006) Characterization of 23 CC chemokine genes and analysis of their expression in channel catfish (ICtalurus punctatus). Dev Comp Immunol 30:783-796.

Bazan JF, Bacon KB, Hardiman G, Wang W, Soo K, Rossi D, Greaves DR, Zlotnik A, Schall TJ (1997) A new class of membrane-bound chemokine with a CX3C motif. Nature 385:640-644.

Beck G, Habicht GS (1996) Immunity and the inverte- 
brates. Sci Am 275:60-66.

Borza T, Stone C, Rise ML, Bowman S, Johnson SC (2010) Atlantic cod (Gadus morhua) CC chemokines: Diversity and expression analysis. Dev Comp Immunol 34:904-913.

Chen SL, Liu Y, Dong XL, Meng L (2010) Cloning, characterization, and expression analysis of a $\mathrm{CC}$ chemokine gene from turbot (Scophthalmus maximus). Fish Physiol Biochem 36: 147-155.

Duesund H, Nylund S, Watanabe K, Ottem KF, Nylund A (2010) Characterization of a VHS virus genotype III isolated from rainbow trout (Oncorhychus mykiss) at a marine site on the west coast of Norway. Virol J 7:19.

Farrell CO, Vaghefi N, Cantonnet M, Buteau B, Boudinot P, Benmansour A (2002) Survey of transcript expression in rainbow trout leukocytes reveals a major contribution of interferon-responsive genes in the early response to a rhabdovirus infection. Virol J 76:8040-8049.

Fischer U, Koppang EO, Nakanishi T (2013) Teleost T and NK cell immunity. Fish Shellfish Immunol 35:197-206.

Grimholt U, Hauge H, Hauge AG, Leong J, Koop BF (2015) Chemokine receptors in Atlantic salmon. Dev Comp Immunol 49:79-95.

Hsu YJ, Hou CY, Lin SJ, Kuo WC, Lin HT, Lin JHY (2013) The biofunction of orange-spotted grouper (Epinephelus coioides) CC chemokine ligand 4 (CCL4) in innate and adaptive immunity. Fish Shellfish Immunol 35:1891-1898.

Isshiki T, Nishizawa T, Kobayashi T, Nagano T, Miyazaki T (2001) An outbreak of VHSV (viral hemorrhagic septicemia virus) infection in farmed Japanese flounder Paralichthys olivaceus in Japan. Dis Aquat Org 47:87-99.

Khattiya R, Ohira T, Hirono I, Aoki T (2004) Identification of a novel Japanese flounder (Paralichthys olivaceus) CC chemokine gene and an analysis of its function. Immunogenetics 55:763-769.

Kim EG (2012) Molecular characterization, expression analysis and biological activity of two chemokines from rock bream (Oplegnathus fasciatus). M.S. Thesis, Gyeongsang National University, Gyeongnam, Korea.

Kim JW, Kim EG, Kim DH, Shim SH, Park CI (2013)

Molecular identification and expression analysis of the $\mathrm{CC}$ chemokine gene in rock bream (Oplegnathus fasciatus) and the biological activity of the recombinant protein. Fish Shellfish Immunol 34:892-901.

Kim KS (2009) Study on early development and metamorphosis of Paralichthys olivaceus. Ph.D. Thesis, Chonnam National University, Chonnam, Korea.

Kim SM, Lee JI, Hong MJ, Park HS, Park SI (2003) Genetic relationship of the VHSV (Viral hemorrhagic septicemia virus) isolated from cultured olive flounder, Paralichthys olivaceus in Korea. J Fish Pathol 16:1-12.

Kim WS, Kim SR, Kim D, Kim JO, Park MA, Kitamura SI, Kim HY, Kim DH, Han HJ, Jung SJ, Oh MJ (2009) An outbreak of VHSV (viral hemorrhagic septicemia virus) infection in farmed olive flounder Paralichthys olivaceus in Korea. Aquaculture 296:165-168.

Knaut H, Werz C, Geisler R, Consortium TTBS, NussleinVolhardC (2003) A zebrafish homologue of the chemokine receptor Cxcr4 is a germ-cell guidance receptor. Nature 421:279-282.

Kong HJ, Hong GE, Kim WJ, Kim YO, Nam BH, Lee CH, Do JW, Lee JH, Lee SJ, Kim KK (2009) Cloning and characterization of hypusine-containing protein eIF5A from the olive flounder Paralichthys olivaceus. Comp Biochem Physiol B 153:281-287.

Lee SH, Lee YM, Kim KH, Kim HC, Park CJ, Park JW, Noh GE, Kim WJ, Hwang HK (2018) Effects of food availability on growth performance and immune-related gene expression of juvenile olive flounder (Paralichthys olivaceus). Fish Shellfish Immunol 80:348-356.

Liston A, McColl S (2003) Subversion of the chemokine world by microbial pathogens. Bioessays 25:478-488.

Luster AD (1998) Chemokines-chemotactic cytokines that mediate inflammation. N Engl J Med 338:436-445.

Magnadottir B (2006) Innate immunity of fish (overview). 
Fish Shellfish Immunol 20:137-51.

Mantovani A (1999) The chemokine system: redundancy for robust outputs. Immunol Today 20:254-257.

Miller MD, Krangel MS (1992) Biology and biochemistry of the chemokines: A family of chemotactic and inflammatory cytokines. Crit Rev Immunol 12:17-46.

Murphy PM (1994) The molecular biology of leukocyte chemoattractant receptors. Annu Rev Immunol 12:593-633.

Murphy PM, Baggiolini M, Charo IF, Hebert CA, Horuk R, Matsushima K, Miller LH, Oppenheim JJ, Power CA (2000) International union of pharmacology. XXII. Nomenclature for chemokine receptors. Pharmacol Rev 52:145-176.

Noh GE, Kim WJ, Kim HC, Park CJ, Park JW (2017) Daily rhythms and effect of short-term starvation on the of health parameters in olive flounder Paralichthys olivaceus. Korean J Fish Aquat Sci 50:534-540.

Oppenheim JJ, Howard OMZ, Goetzl E (2001) Chemotactic factors, neuropeptides, and other ligands for seven transmembrane receptors. In: Oppenheim JJ, Feldmann M, Durum SK (ed), Cytokine Reference: A Compendium of Cytokines and Other Mediators of Host Defence. Academic Press, London, pp 985-1021.

Pan Y, Lloyd C, Zhou H, Dolich S, Deeds J, Gonzalo JA, Vath J, Gosselin M, Ma J, Dussault B, Woolf E, Alperin G, Gulpepper J, Gutierrez-Ramos JC, Gearing D (1997) Neurotactin, a membrane-anchored chemokine upregulated in brain inflammation. Nature 387:611-617.

Pereiro P, Figueras A, Novoa B (2016) Turbot (Scophthalmus maximus) vs. VHSV (viral hemorrhagic septicemia virus): A review. Front Physiol 7:192.
Pinheiro ACAS, Volpe E, Principi D, Prosperi S, Ciulli S (2016) Development of a multiplex RT-PCR assay for simultaneous detection of the major viruses that affect rainbow trout (Oncorhynchus mykiss). Aquac Int 115-125.

Semple SL, Eshaque S, Fujiki K, Tang C, Mitchell L, Bols NC, Dixon B (2018) CK-2 of rainbow trout (Oncorhynchus mykiss) has two differentially regulated alleles that encode a functional chemokine. Vet Immunol Immunopathol 198:26-36.

Taub DD, Oppenheim JJ (1993) Review of the chemokine meeting the third international symposium of chemotactic cytokines. Cytokine 5:175-179.

Tian C, Chen Y, Ao J, Chen X (2010) Molecular characterization and bioactivity of a CXCL13 chemokine in large yellow croaker Pseudosciaena crocea. Fish Shellfish Immunol 28: 445-452.

Uribe C, Folch H, Enriquez R, Moran G (2011) Innate and adaptive immunity in teleost fish: A review. Vet Med 56:486-503.

Xu TJ, Cheng YZ, Shi G, Wang RX (2011) Molecular cloning, characterization, and expression analysis of a disease-resistance related $\mathrm{CC}$ chemokine gene in miiuy croaker (Miichthys miiuy). Aquaculture 318:25-32.

Zapata AG, Torroba M, Varas A, Jimenez E (1997) Immunity in fish larvae. Dev Biol Stand 90:23-32.

Zhang JZ, Chen XH (2008) Molecular characterization of a novel CC chemokine in large yellow croaker (Pseudosciaena crocea) and its involvement in modulation of MHC class I antigen processing and presentation pathway. Mol Immunol 45:2076-2086. 